\title{
Strategies of Modeling, Monitoring, Professional Dialogue and the Effectiveness of Principal Leadership to Teachers During the Pandemic of Covid-19
}

\author{
Pramono $^{1}$, Muh. Arafik ${ }^{2}$, Ahmad Nurabadi ${ }^{3}$, Teguh Triwiyanto ${ }^{4}$ \\ 1,2Jurusan Kependidikan Sekolah Dasar dan Pra Sekolah, Fakultas Ilmu Pendidikan \\ ${ }^{3,4}$ Jurusan Administrasi Pendidikan, Fakultas Ilmu Pendidikan \\ Universitas Negeri Malang \\ Jl. Semarang No. 5 Kota Malang, Jawa Timur, Indonesia \\ E-mail: pramono.fip@um.ac.id
}

Article received : August 2021; revised : August 2021 ; accepted : August 2021

DOI : $10.17977 /$ um025v5i32021p154

\begin{abstract}
The purpose of this study was to determine the strategies of modeling, monitoring, professional dialogue, and the effectiveness of the principal's learning leadership to teachers during the novel coronavirus disease (COVID-19) pandemic. A quantitative approach was used in this research. The population of this research is the principals of public elementary schools in Malang City, Malang Regency, and Batu City, East Java Province, Indonesia, amounting to 1,323 . The sample selection used was random sampling, with a total of 290 people or 22 percent of the population. Data analysis used path coefficient analysis. The results showed that strategies of modeling, monitoring, and professional dialogue affected the effectiveness of learning leadership during the COVID-19 pandemic.
\end{abstract}

Keywords: strategy; modeling; monitoring; professional dialogue; effectiveness of learning leadership; COVID-19 pandemic

learning leadership strategies are defined as school management efforts to achieve the effectiveness of educational goals. The principal as the top leader in the education unit needs to continue to develop ideas in the practice of learning strategies. This learning leadership of the principal describes a process of developing and using a mix of theoretical and practical knowledge specific to an educational context, a set of principles for learning leadership as well as learning leadership. The learning leadership strategies stated by Southworth (2002) there are three strategies to improve learning, namely modeling, monitoring, and professional dialogue.

To achieve the effectiveness of learning leadership, it must not only be sought by the principal, but also by the teachers, because the teachers are the leaders for students in the class during learning. As stated by Day, Gu \& Sammons (2016:221) that the ability of schools to improve and maintain effectiveness in the long term is not primarily the result of the principal's leadership style, but from the understanding and diagnosing school needs, and the application of clearly articulated educational values which are organized organizationally through various of time and strategies combination and accumulation, and context-sensitive strategies that are layered and increasingly embedded in work, culture, and school achievement. The principal's role towards teachers, as stated by Murtiningsih, Kristiawan \& Lian (2019:246) is to maintain relationships in learning supervision, interpersonal communication, and principal interpersonal communication to encourage and strengthen the teacher's work ethic.

The principal's greatest role in learning leadership is to optimally organize internal and external resources to improve learning outcomes. This organizational capacity is a managerial aspect of the principal, which requires leadership aspects, for the context of learning, it is commonly referred to as learning leadership. 
The principal's learning leadership, all of which was conveyed above, occurs in normal situations, unlike when schools face abnormal situations, such as what is happening now, in the form of a novel coronavirus disease (COVID-19) pandemic. When it's normal, it requires various leadership capacities of school principals and teachers, especially when the conditions are uncertain due to the pandemic.

The pandemic declared by the World Health Organization (WHO) as coronavirus disease 2019 (covid-19), caused by acute respiratory syndrome coronavirus 2 (sars-CoV-2), became a pandemic on 12 March 2020. On 18 March 2020 United Nations Educational The Scientific and Cultural Organization (UNESCO) estimates that 107 countries have implemented national school closures due to COVID-19, which affects 862 million children and youth, roughly half of the global student population. School closures make learning done online, learning from home, while still using the curriculum and materials as normal.

Currently, during the pandemic of covid-19, students study at home, the principal makes himself a model, meaning that the example of the principal becomes an example or model that is imitated by the teachers in the school he leads. During the pandemic of covid-19, students study at home, the school principal carries out monitoring, which means monitoring teacher performance when teachers carry out the learning process and taking advantage of the results of this monitoring for further guidance. Professional dialogue means discussing actively, interactively, effectively, aspirationally, inspiringly, productively, democratically, and scientifically about the results of performance appraisals and follow-up plans to improve the quality of student learning processes and outcomes. Lancker \& Parolin (2020:e243) stated during a pandemic like this, teachers should consider how to adapt their study materials for students without access to wireless internet, computers, or study places. At the local level, adequate responses should include targeted education and material support for children from low-income households to begin closing possible learning gaps.

Based on the explanation above, the purpose of this study is to find out the strategy of modeling, monitoring, professional dialogue, and the effectiveness of the principal's learning leadership to teachers during the novel coronavirus disease (covid-19) pandemic.

\section{METHODS}

This study uses a survey method with a causal technique. The collected data were analyzed by path analysis. The analysis is used to see the effect of one variable on another variable. There are two kinds of variables studied, namely exogenous variables and endogenous variables. Exogenous variables have a direct or indirect influence on endogenous variables. Endogenous variables are variables that can affect other endogenous variables. The endogenous variable in this study is the effectiveness of learning leadership (X4). Exogenous variables include modeling strategy (X1), monitoring strategy (X2), and professional dialogue (X3).

The population of this research is the principals of public elementary schools in Malang City, Malang Regency, and Batu City, amounting to 1,323. The sample selection used was random sampling, with a total of 290 people or 22 percent of the population. The sampling technique used is Simple Random Sampling. Data was collected using a research instrument in the form of a questionnaire. The scale used is the Rating Scale with five categories of answer choices, namely (a) always; (b) often; (c) sometimes; (d) rarely; and (e) never.

The instrument was tested first before being used in this research. The instrument testing includes a validity test and a reliability test. The test results obtained valid and invalid instrument items. Invalid instruments were not used in this research. Data analysis in this research employs a path coefficient test.

\section{RESULTS AND DISCUSSION}

This research shows that there is a direct effect of modeling strategy on professional dialogue by 0.126 . Meanwhile, the direct effect of monitoring strategy on professional dialogue is 0.737 . The 
influence of other variables on professional dialogue is 0.28 principals to teachers during the pandemic of covid-1. Table 1 shows the recapitulation of the results of hypothesis testing.

Table 1. Recapitulation of the Results of Hypothesis Testing

\begin{tabular}{|c|c|c|c|c|}
\hline No & Hypothesis & Statistic test & Decision of $\mathrm{Ho}$ & Conclusion \\
\hline 1 & $\begin{array}{l}\text { There is a direct effect of modeling strategies on } \\
\text { professional dialogue. }\end{array}$ & $\begin{array}{l}\text { Ho: } \rho 31=0 \\
\text { H1: } \rho 31>0\end{array}$ & Ho rejected & Direct effect \\
\hline 2 & $\begin{array}{l}\text { There is a direct effect of monitoring strategies on } \\
\text { professional dialogue. }\end{array}$ & $\begin{array}{l}\mathrm{H} 1: \rho 32=0 \\
\mathrm{H} 1: \rho 31>0\end{array}$ & Ho rejected & Direct effect \\
\hline 3 & $\begin{array}{l}\text { There is a direct effect of modeling strategy on the } \\
\text { effectiveness of learning leadership. }\end{array}$ & $\begin{array}{l}\text { Ho: } \rho 41=0 \\
\text { H1: } \rho 41>0\end{array}$ & Ho rejected & Direct effect \\
\hline 4 & $\begin{array}{l}\text { There is a direct effect of monitoring strategy on } \\
\text { the effectiveness of learning leadership. }\end{array}$ & $\begin{array}{l}\text { Ho: } \rho 42=0 \\
\text { H1: } \rho 42>0\end{array}$ & Ho rejected & Direct effect \\
\hline 5 & $\begin{array}{l}\text { There is a direct effect of professional dialogue on } \\
\text { the effectiveness of learning leadership. }\end{array}$ & $\begin{array}{l}\text { Ho: } \rho 43=0 \\
\text { H1: } \rho 43>0\end{array}$ & Ho rejected & Direct effect \\
\hline 6 & $\begin{array}{l}\text { There is an indirect effect of modeling strategy on } \\
\text { learning leadership through professional dialogue. }\end{array}$ & $\begin{array}{l}\text { Ho: } \rho 413=0 \\
\text { H1: } \rho 413>0\end{array}$ & Ho rejected & Indirect effect \\
\hline 7 & $\begin{array}{l}\text { There is an indirect effect of monitoring strategy } \\
\text { on learning leadership through professional } \\
\text { dialogue. }\end{array}$ & $\begin{array}{l}\text { Ho: } \rho 423=0 \\
\text { H1: } \rho 423>0\end{array}$ & Ho rejected & Indirect effect \\
\hline
\end{tabular}

Based on the results of the calculation and testing of the path coefficients, it can be interpreted the magnitude of the direct influence of exogenous variables on endogenous variables. The results of the study prove that the direct influence of modeling strategies on the effectiveness of learning leadership is 0.16 , the magnitude of the influence of monitoring strategies on the effectiveness of learning leadership is 0.35 , and the large influence of professional dialogue on the effectiveness of learning leadership is 0.24 principals to teachers during the pandemic of covid-19. The final structural model of the intervariable influence on the results of hypothesis testing is presented in Figure 1.

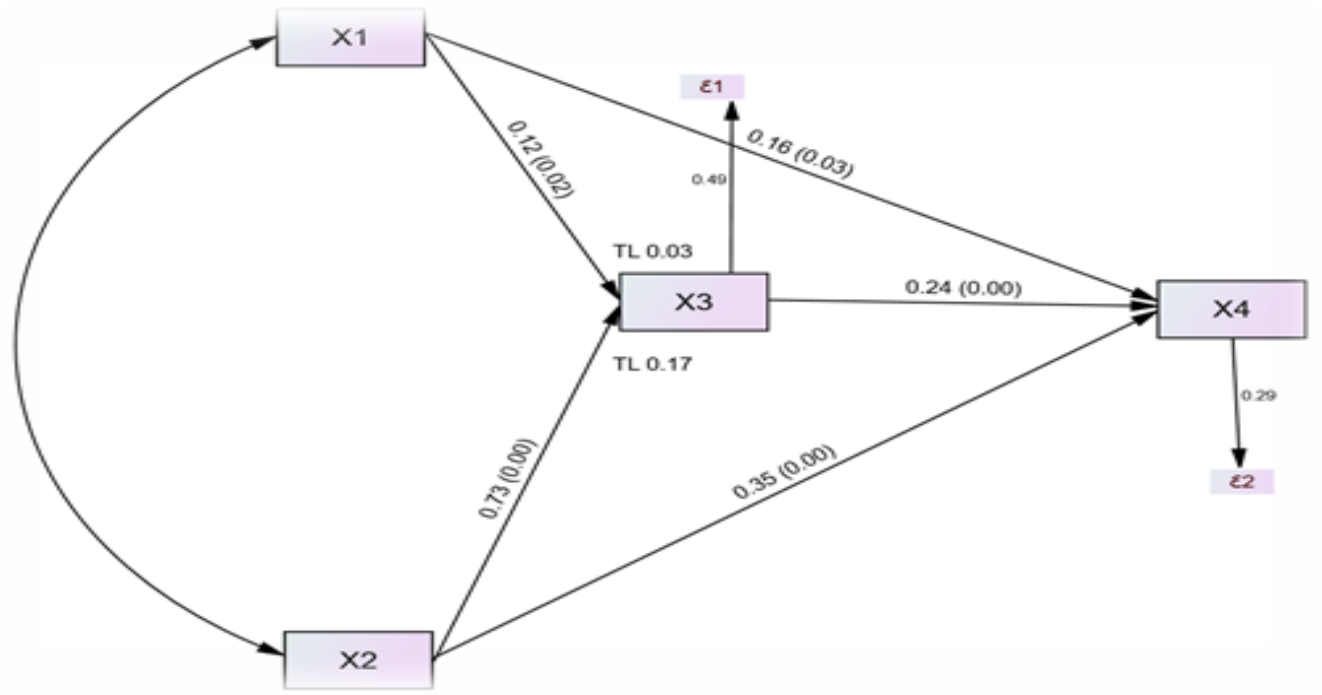

Figure 1. Path Coefficient and Effect of Exogenous Variables on Endogenous Variables

Information:

The direct influence path coefficient consists of $0.12 ; 0.73 ; 0.16 ; 0.35$; and 0.24 .

The indirect effect path coefficient (TL) consists of 0.03 and 0.47 .

The correlation coefficient consists of (0.02); (0.00); (0.03); (0.35); and (0.00). 
The results of the study also confirm that the modeling strategy besides having a direct effect also shows an indirect effect on the effectiveness of learning leadership through professional dialogue. The indirect effect of modeling strategy through professional dialogue on the effectiveness of learning leadership is 0.03 . Thus, the total effect of modeling strategies on the effectiveness of learning leadership, both directly and indirectly, is 0.19 principals to teachers during the pandemic of covid- 19 .

Similar to the modeling strategy, the results of the study also prove that in addition to having a direct effect on the effectiveness of learning leadership, the monitoring strategy also has an indirect effect on the effectiveness of learning leadership through professional dialogue. The indirect effect of monitoring strategy through professional dialogue on the effectiveness of learning leadership is 0.52 . Thus, the total influence of the monitoring strategy on the effectiveness of learning leadership, both directly and indirectly, is 0.24 principals to teachers during the pandemic of COVID-19.

The sudden arrival of the pandemic of COVID-19 has forced schools to prepare an education system to prevent the spread of this deadly virus. Schools under the leadership of the principal strive to continue learning. Therefore, the principal's learning leadership to teachers is essential during the pandemic. Beteille, et al (2020) stated that the sudden closure of schools during the pandemic of COVID-19 has left many teachers in some countries uncertain about their role, unable to use technology effectively to communicate and teach, and unprepared for classroom challenges when schools open back online. For the central role that teachers play in student learning, there are three main principles of the COVID-19 education policy response: overcoming, managing continuity, and improving and accelerating.

The central role of the teacher is under the coordination of the principal, who during the pandemic of COVID-19 situation is increasingly difficult to carry out normally, then online learning becomes an option. Online learning is the choice of schools in most countries in the world. Demuyakor (2020) stated that the implementation of online learning programs is a very good idea, students have adequate knowledge about the pandemic of COVID-19. Another finding that emerged during the study was the high cost of participating in online learning. However, our results show that students in China, because of the pandemic of COVID-19 spent so much money to buy internet data for online learning. ManningOuellette \& Black (2017) stated that online students can engage more frequently in deeper learning about assignments than in traditional classroom environments.

The principal's learning leadership was tested during this pandemic of COVID-19, how to adapt quickly to situations and conditions that were vulnerable to deadly viruses. Such a situation requires good learning leadership, Fernandez \& Shaw (2020) stated that in the future it will require flexible leaders with adaptive capacity to learn and thrive in crises, to emerge more capable of overcoming future crises. Learning leaders must distribute leadership responsibilities to a network of teams across the organization to improve the quality of decisions made in crisis resolution.

The exponential study of learning leadership is an attempt to make an effort to produce an effective and efficient education, especially to produce optimal student achievement. Gumus, Bellibas, Esen \& Gumus (2018) mentioned that the most recent and widely studied studies in current educational research are mainly related to distributed leadership, learning leadership, teacher leadership, and transformational leadership. It was also found that related research has increasingly focused on the effects of leaders on organizational behavior/conditions and student achievement. Boyce \& Bowers (2018) stated that there are four main themes of instructional leadership research, namely principals' leadership and influence, teacher autonomy and influence, adult development, and school climate.

The results of this study indicate that the principal's modeling strategy for teachers is not only having a direct effect, also showing an indirect effect on the effectiveness of learning leadership through professional dialogue during the pandemic of COVID-19, that the learning leadership of school principals needs to get support from teachers and good school management, for optimizing the quality of education. Liu \& Hallinger (2018) added that there is a positive relationship between principal leadership and teacher professional learning and emphasize the importance of self-efficacy in shaping educator practice. Manaseh (2016) stated that without effective management of teaching programs in support of promoting teacher classroom teaching and student learning, attempts to affect it are doomed to failure. 
The modeling strategy to encourage the effectiveness of learning leadership carried out by school principals to teachers, the results of research based on the high and low indicators, can be categorized into two groups. First, included in the groups that are often carried out by school principals, namely: providing examples to teachers regarding positive attitudes towards students, providing examples to teachers regarding flexibility in learning approaches, providing examples to teachers regarding effective communication, and providing examples to teachers regarding giving good grades and fair as long as students study at home. Second, included in the group that is rarely carried out by principals, namely: providing examples to teachers regarding the good material organization, good student learning outcomes, enthusiasm for subject matter, and mastery of subject matter while students study at home.

Terdapat banyak strategi untuk pengembangan kepemimpinan, Turner, J.R., Baker, Schroeder, Johnson \& Chung (2018) mengkategorikan lebih dari 500 teknik pengembangan kepemimpinan. Grunberg, dkk (2019) menyatakan untuk pendidikan dibutuhkan strategi pengembangan kepemimpinan untuk memandu kurikulum, penilaian siswa, sekolah, dan program. Kepemimpinan tersebut mencakup empat unsur, yaitu karakter, kompetensi, konteks, dan komunikasi - yang melintasi empat tingkat interaksi psikososial - pribadi, interpersonal, tim, dan organisasi.

Various variables influence learning leadership for satisfactory results. Louis \& Huang (2016) stated that the learning climate in schools is the most important factor linking principal leadership and student achievement growth. Furthermore, this relationship is fully mediated through the teacher's influence in the decision-making process. The quality of programs in schools - how diverse the programs are coherent and the quality development they have - also directly links principal leadership to student achievement. Hallinger (2005) mentioned that leadership and school effectiveness show that leadership has a significant, but indirect, influence on student learning achievement.

Monitoring strategies to encourage the effectiveness of learning leadership carried out by school principals to teachers, from the results of this study can be classified based on high and low frequency, into two groups. First, high-frequency groups, which means that school principals always do this, namely: during the pandemic of COVID-19 and students study at home, school principals carry out learning monitoring to motivate teachers, learning monitoring becomes feedback for improving school program activities, learning monitoring provides good benefits for schools, and learning monitoring is oriented to the applicable regulations. Second, groups with low frequency, means that the principal is rarely carried out, namely: monitoring learning is carried out continuously, monitoring learning motivates students to excel, monitoring learning provides good benefits to parents, and monitoring learning objectively.

A comprehensive principal leadership strategy during school reform was carried out on a large scale in Finland. Soini, Pietarinen \& Pyhältö (2016) stated that inclusive and learning-oriented strategies are applied fairly consistently in horizontal terms, but not so much in establishing vertical coherence. The exclusive strategy is used to reduce teacher workload. Principals' efforts focus on creating and protecting teacher opportunities for meaningful learning.

Teachers who are executors of learning in the classroom, principals create by encouraging better teacher performance, because student achievement is not directly related to the principal's learning leadership, as stated by Nurjaningsih (2020) that the learning strategy variable is a significant mediator in the relationship between the independent motivation variable and the dependent variable in improving the principal's technological leadership which the gender factor as a moderator is so strong. Motivation by using learning strategies in the principal training curriculum that integrates information technology can improve the principal's leadership.

The results of this study also confirm that besides the direct and indirect influence of modeling strategies and monitoring strategies on the principal's learning leadership to teachers, professional dialogue is also an intervening variable that has an influence. The results of this study are in line with what Chien (2018) said that the topics and formats of professional dialogue, as well as the attributes of teachers and instructional leadership, are considered important factors that influence the effectiveness of professional dialogue. Chien (2020) stated that professional dialogue for professional development requires: First, the knowledge and skills included in the professional dialogue of teachers concerned 
with planning, implementing, and managing instruction. Second, teachers perceive their professional dialogue as effective and goal-oriented.

The results of this study also identify professional dialogue to encourage the effectiveness of learning leadership that is carried out by school principals to teachers based on high and low frequency, which can be categorized into two groups. The first group, with a high frequency, means that the principal is always carried out, namely: during the pandemic of COVID-19, when students study at home, the principal and the teacher engages in an active dialogue conducting an aspirational dialogue and a productive dialogue about the results of performance assessments to improve the quality of learning student. Second, groups with low frequency, it means that school principals rarely do this, namely: conducting effective dialogues, discussing democratic dialogues, and conducting dialogues that discuss scientifically the results of performance assessments to improve the quality of student learning.

To produce an effective professional dialogue between principals and teachers, various innovations in school operations are needed. Tsai, Poquet, Gašević, Dawson \& Pardo (2019) stated the main challenge related to learning activities, which lies in the inherent tension between innovation and operations. These challenges require new forms of leadership to create and maintain an adaptive space in which innovation is supported and ultimately transformed into the mainstream operations of an institution. That is the complexity leadership model allows education to shift to a more fluid and dynamic approach to the adoption of learning activities, thereby ensuring its stability and sustainability.

\section{CONCLUSION}

Based on the results of the calculation and testing of the path coefficients, it can be interpreted the magnitude of the direct influence of exogenous variables on endogenous variables. The results also confirm that the modeling strategy not only having a direct effect but also showing an indirect effect on the effectiveness of learning leadership through dialogue. It is similar to the modeling strategy, the results of the study also prove that besides having a direct effect on the effectiveness of learning leadership, the monitoring strategy also showing an indirect effect on the effectiveness of learning leadership through professional dialogue during the pandemic of COVID-19.

\section{REFERENCES}

Beteille, Tara Ding., Elaine, Molina., Ezequiel, Pushparatnam., \& Adelle Wilichowski, Tracy. 2020. Three Principles to Support Teacher Effectiveness during Covid-19. Washington, D.C: World Bank. DOI:10.1596/33775.

Boyce, J. \& Bowers, A.J. 2018. Toward an evolving conceptualization of instructional leadership as leadership for learning: Meta-narrative review of 109 quantitative studies across 25 years. Journal of Educational Administration, 56(2), 18-29. DOI.10.1108/JEA-06-2016-0064.

Chien, Chin-Wen. 2018. Professional dialogue among elementary school English teachers in Taiwan: current challenges and issues, Education 3-13, 46:2, 188-201, DOI: $10.1080 / 03004279.2016 .1217249$

Chien, Chin-Wen. 2020. Analysis of Elementary School English Teachers' Professional Dialogue as Their Professional Development. Australian Journal of Teacher Education, 45(5), 1-17. DOI.10.14221/ajte.2020v45n5.1

Day, C., Gu, Q., \& Sammons, P. 2016. The Impact of Leadership on Student Outcomes: How Successful School Leaders Use Transformational and Instructional Strategies to Make a Difference. Educational Administration Quarterly, 52(2), 221-258. https://doi. org/10.1177/0013161X15616863. 
Demuyakor, J. 2020. Coronavirus (COVID-19) and Online Learning in Higher Institutions of Education: A Survey of the Perceptions of Ghanaian International Students in China. Online Journal of Communication and Media Technologies, 10(3), e202018. https://doi. org/10.29333/ojcmt/8286

Fernandez, A.A. \& Shaw, G.P. 2020, Academic Leadership in a Time of Crisis: The Coronavirus and Covid-19. Journal Leadership Studies, 14 (1), 39-45. doi:10.1002/jls.21684.

Grunberg, Neil E., Barry, Erin S., Callahan, Charles W., Kleber, Hannah G., McManigle, John E., \& Schoomaker, Eric B. 2019. A conceptual framework for leader and leadership education and development. International Journal of Leadership in Education, 22(5), 644650. DOI: 10.1080/13603124.2018.1492026.

Gumus, S., Bellibas, M. S., Esen, M., \& Gumus, E. 2018. A systematic review of studies on leadership models in educational research from 1980 to 2014. Educational Management Administration \& Leadership, 46(1), 25-48. https://doi.org/10.1177/1741143216659296

Hallinger, Philip. 2005. Instructional Leadership and the School Principal: A Passing Fancy That Refuses to Fade Away. Leadership and Policy in Schools, 4 (3): 221-39.

Hallinger, Philip., \& R. H. Heck. 1996.Reassessing the Principal's Role in School Effectiveness: A Review of Empirical Research, 1980-1995. Educational Administration Quarterly, 32 (1): 5-44.

Lancker, Wim Van., \& Parolin, Zachary. 2020. Covid-19, school closures, and child poverty: a social crisis in the making. The Lancet Public Health, 5(5), e243-e244. https://doi. org/10.1016/S2468-2667(20)30084-0.

Liu, S., \& Hallinger, P. 2018. Principal Instructional Leadership, Teacher Self-Efficacy, and Teacher Professional Learning in China: Testing a Mediated-Effects Model. Educational Administration Quarterly, 54(4), 501-528. https://doi.org/10.1177/0013161X18769048

Louis, Karen Seashore, Leithwood, Kenneth., Wahlstrom, Kyla., \& Anderson, Stephen. 2010. Learning from Leadership Project: Investigating the Links to Improved Student Learning. New York: Wallace Foundation.

Manaseh, Aaron Mkanga. 2016. Instructional Leadership: The Role Of Heads Of Schools In Managing The Instructional Programme. International Journal of Educational Leadership and Management, 4(1), 30-47. doi:http://dx.doi.org/10.17583/ijelm.2016.1691.

Manning-Ouellette, A., \& Black, K. M. 2017. Learning Leadership: A Qualitative Study on the Differences of Student Learning in Online versus Traditional Courses in a Leadership Studies Program. Journal of Leadership Education, 16(2), 59-79.

Murtiningsih, M., Kristiawan, M., \& Lian, B. 2019. The Correlation between Supervision of Headmaster and Interpersonal Communication with Work Ethos of the Teacher. European Journal of Education Studies, 6(1), 245-256. doi:http://dx.doi.org/10.46827/ejes.v0i0.2398.

Nurjaningsih, S. (2020). Analysis of Principal's Motivation and Leadership Technology Pathway through Mediator Learning Strategies with Gender Moderators in Maya Seesaw Classes. Social Science Learning Education Journal, 5(1), 231-242.

Sebastian, James, and Elaine Allensworth. 2012. The Influence of Principal Leadership on Classroom Instruction and Student Learning: A Study of Mediated Pathways to Learning. Educational Administration Quarterly, 48 (4): 626-63.

Sebastian, James., Allensworth, Elaine., \& Huang, Haigen. 2016. The Role of Teacher Leadership in How Principals Influence Classroom Instruction and Student Learning. American Journal of Education, 123(1), 69-108 
Soini, Tiina., Pietarinen, Janne \& Pyhältö, Kirsi. 2016. Leading a school through change - principals' hands-on leadership strategies in school reform, School Leadership \& Management, 36(4), 452-469. DOI: 10.1080/13632434.2016.1209179.

Southworth, Geoff. 2002. Instructional Leadershipin Schools: Reflections and empirical evidence, School Leadership \& Management, 22(1), 73-91. DOI: 10.1080/13632430220143042.

Tsai, Y.S., Poquet, O., Gašević, D., Dawson, S., \& Pardo, A. 2019, Complexity leadership in learning analytics: Drivers, challenges and opportunities. British Educational Research Journal, 50(1), 2839-2854. DOI:10.1111/bjet.12846

Turner, J.R., Baker, R., Schroeder, J., Johnson, K.R. and Chung, C.-h. 2018. Leadership development techniques: Mapping leadership development techniques with leadership capacities using a typology of development. European Journal of Training and Development, 42(9), 538-557. DOI: 10.1108/EJTD-03-2018-0022.

United Nations Educational, Scientific and Cultural Organization. 2020. Retrieved July 9, 2020, from https://en.unesco.org/covid19/educationresponse/globalcoalition.

World Health Organization. 2020. Coronavirus disease (Covid-19) pandemic. Retrieved July 12, 2020, from https://www.who.int/emergencies/diseases/novel-coronavirus-2019. 